\title{
AWARENESS OF TICK-BORNE BACTERIAL INFECTION IN THE STUDENTS OF NON-MEDICAL UNIVERSITIES IN TERNOPIL REGION (WESTERN UKRAINE)
}

\section{ŚWIADOMOŚĆ STUDENTÓW KIERUNKÓW NIEMEDYCZNYCH W TARNOPOLU (UKRAINA ZACHODNIA) W ZAKRESIE RYZYKA ZAKAŻEŃ PATOGENAMI PRZENOSZONYMI PRZEZ KLESZCZE}

\author{
Svitlana Nykytyuk ${ }^{1(A, B, C, D, E, F)}$, Anna Pańczuk ${ }^{2(A, B, D)}$, Mariia Shkilna $^{1(A, B, C, D, E, F)}$, \\ Małgorzata Tokarska-Rodak $^{3(\mathrm{~A}, \mathrm{~B}, \mathrm{D})}$, Adam Szepeluk ${ }^{4(\mathrm{C})}$, \\ Larysa Melnyk $^{1(\mathrm{C})}$, Mykhailo Korda ${ }^{1(\mathrm{~A}, \mathrm{~B}, \mathrm{D}, \mathrm{E})}$
}

${ }^{1}$ I. Horbachevsky Ternopil State Medical University, Ukraine ${ }^{2}$ Institute of Physical Education and Physiotherapy, Pope John Paul II State School of Higher Education in Biala Podlaska, Poland

${ }^{3}$ Institute of Health Sciences, Pope John Paul II State School of Higher Education in Biala Podlaska, Poland ${ }^{4}$ Innovation Research Centre, Pope John Paul II State School of Higher Education in Biala Podlaska, Poland

Authors' contribution

Wkład autorów:

A. Study design/planning

zaplanowanie badań

B. Data collection/entry

zebranie danych

C. Data analysis/statistics

dane - analiza i statystyki

D. Data interpretation

interpretacja danych

E. Preparation of manuscript przygotowanie artykułu

F. Literature analysis/search wyszukiwanie i analiza literatury

G. Funds collection

zebranie funduszy
Tables: 4

Figures: 0

References: 8

Submitted: 2017 May 31

Accepted: 2017 Jun 20

\section{Summary}

Background. The aim of the study was to evaluate the awareness of Lyme borreliosis prevention and exposure to ticks in non-medical students of 2 universities in Ternopil Region (Western Ukraine). Material and methods. The study was conducted by surveying 252 young persons studying at non-medical universities in Ternopil (Western Ukraine): 119 students of Ternopil Volodymyr Hnatyuk National Pedagogical University (TNPU) and 133 of Ternopil Ivan Puluj National Technical University (TNTU), aged 18-23 years old. All the participants completed a questionnaire. Results. The students of Ternopil Volodymyr Hnatyuk National Pedagogical University (TNPU) and Ternopil Ivan Puluj National Technical University (TNTU), Ternopil, understand that the risk of being infected with Lyme borreliosis does not only appear in forests, but also in gardens, parks, and countryside. Still, $16.5 \%$ of the students of both Ternopil universities showed very low awareness about Lyme borreliosis. Most TNPU respondents in the study group (40.7\%) were bitten by a tick in the abdomen area; $31.3 \%$ of the TNTU students declared being bitten in lower limbs. Students of both universities recorded the fewest bites in the chest area $(7.1 \%$ in TNTU and $13.0 \%$ in TNPU respectively). As for the most frequent methods of tick removal, $71.4 \%$ of the respondents lubricated it with fat (e.g. butter, oil) and $42.0 \%$ twisted it out with tweezers.

Conclusions. Education towards proper methods of tick removal, prevention of tick bites (clothes, repellents) should become an important element of protection measures in students in the regions of high Lyme borreliosis frequency, including Ternopil.

Keywords: Lyme borreliosis, knowledge, prevention, students, Ternopil (Western Ukraine)

\section{Streszczenie}

Wprowadzenie. Celem pracy była ocena świadomości studentów na kierunkach niezwiązanych z medycyną na dwóch uniwersytetach $w$ regionie Tarnopola (Zachodnia Ukraina) w zakresie zapobiegania boreliozie z Lyme. Materiał i metody. Badanie zostało przeprowadzone wśród 252 młodych osób studiujących na uniwersytetach w Tarnopolu (Zachodnia Ukraina): 119 studentów z Narodowego Uniwersytetu Pedagogicznego im. Hnatyuka (TNPU) oraz 133 z Narodowego Uniwersytetu Technicznego im. Ivana Pulugo (TNTU) w wieku 18 lat - 23 lata. Jako narzędzie badawcze wykorzystano autorski kwestionariusz ankiety. Wyniki. Studenci z Narodowego Uniwersytetu Pedagogicznego (TNPU) i Narodowego Uniwersytetu Technicznego (TNTU) w Tarnopolu rozumieją, że ryzyko zarażenia boreliozą z Lyme pojawia się nie tylko w lasach, ale także w ogrodach, parkach i na wsi. Mimo to, 16,5\% studentów szkół wyższych w Tarnopolu wykazało bardzo małą świadomość na temat tej choroby. Większość respondentów z TNPU, w grupie badanej $(40,7 \%)$, została ugryziona przez kleszcze w okolicy brzucha; 31,3\% uczniów TNTU stwierdziło, iż zostali pogryzieni w okolicach kończyn dolnych. Studenci obu uczelni zanotowali najmniej pogryzień na klatce piersiowej (odpowiednio 7,1\% w TNTU i 13,0\% w TNPU). Jeśli chodzi o najczęstsze metody usuwania kleszczy, 71,4\% respondentów stwierdziło, iż smarowało kleszcza tłuszczem (np. masłem, olejem) zaś $42,0 \%$ pozbyło się go za pomocą pincety.

Wnioski. Edukacja na temat właściwych metod usuwania kleszczy, zapobiegania pogryzieniu (odzież, środki odstraszające) powinna stać się ważnym elementem środków ochronnych u studentów w regionach o wysokiej częstości występowania boreliozy z Lyme, w tym w Tarnopolu.

Słowa kluczowe: borelioza z Lyme, wiedza, zapobieganie, studenci, Tarnopol (Zachodnia Ukraina)

Nykytyuk S, Pańczuk A, Shkilna M, Tokarska-Rodak M, Szepeluk A, Melnyk L, et al. Awareness of tick-borne bacterial infection in the students of nonmedical universities in Ternopil region (western Ukraine). Health Problems of Civilization. 2017; 11(2): 99-102. doi: 10.5114/hpc.2017.69026.

Address for correspondence / Adres korespondencyjny: Svitlana Nykytyuk, I. Horbachevsky Ternopil State Medical University, m.Voli, 1, Ternopil, 46001, Ukraine, e-mail: nadiya20743@gmail.com, phone: +380 352524492

Copyright: (c) 2017 Pope John Paul II State School of Higher Education in Biała Podlaska, Svitlana Nykytyuk, Anna Pańczuk, Mariia Shkilna, Małgorzata TokarskaRodak, Adam Szepeluk, Larysa Melnyk, Mykhailo Korda. This is an Open Access journal, all articles are distributed under the terms of the Creative Commons Attribution-NonCommercial-ShareAlike 4.0 International (CC BY-NC-SA 4.0) License (http://creativecommons.org/licenses/by-nc-sa/4.0/), allowing third parties to copy and redistribute the material in any medium or format and to remix, transform, and build upon the material, provided the original work is properly cited and states its license. 


\section{Introduction}

Lyme disease (also known as systemic disease, Lime borreliosis or chronic migratory erythema) is a naturalfocal disease transmitted by Borrelia burgdorferi. It is spread by ticks, and manifests itself by migratory ringshaped erythema, fever, disorders of central and peripheral nervous system, heart and large joints [1]. Cases of that disease have been reported in large areas of Eurasian forests and forest-steppe zones [2, 3]. Western Ukraine, including Ternopil Region, is an endemic territory of Lyme borreliosis [3]. The main natural reservoir of Borrelia burgdorferi sensu lato are Ixodes mites. The territories where ticks of the genus Ixodes were found comprise 57 settlements in 14 districts of our region and in the city of Ternopil [4]. Typically, primary lesions appear in spring and summer, which is determined by the period of tick activity [5]. However, the highest morbidity rates are recorded in the countries of Central Europe, Scandinavia and the Baltic States [6].

The aim of the study was to evaluate the awareness of Lyme borreliosis prevention and exposure to ticks in non-medical students of 2 Ternopil universities: Volodymyr Hnatyuk National Pedagogical University (TNPU) and Ivan Puluj National Technical University (TNTU).

\section{Material and methods}

The study group consisted of 252 young people, aged 18-23 years old (=18.4 \pm 1.0$)$, who were examined because of high risk of exposure to Lyme borreliosis: 119 students (47.2\%) represented Volodymyr Hnatyuk National Pedagogical University (TNPU), and 133 (52.8\%) - Ivan Puluj National Technical University (TNTU).

The main research tool was a questionnaire which consisted of 15 questions. The inquiries concerned possible preventive measures taken while staying in the areas where ticks prevail, i.e. the use of repellents and examining the body after returning from the green areas, as well as the awareness of the correct methods of tick removal from the skin. Students of two different universities were also asked to assess their own knowledge on prevention of tick-borne diseases and to evaluate the awareness. Besides, the respondents indicated whether they had been bitten by ticks. The results of the study were subjected to statistical analysis.

In order to test whether the above mentioned variables are independent of each other the Pearson's chisquared test $\left(\chi^{2}\right)$ was used. For statistical inference, the significance level of 0.05 was chosen. Statistical analyses were performed by STATISTICA Software v. 10 (StatSoft, Poland).

\section{Results}

Measures taken to prevent Lyme borreliosis and ticks associated diseases

Table 1. Areas to apply a repellent most often indicated by the surveyed non-medical students of TNTU and TNPU

\begin{tabular}{|c|c|c|c|c|}
\hline & In the forest & In the park & In the garden & On the meadows \\
\hline TNTU & $98.5 \%$ & $79.7 \%$ & $57.9 \%$ & $19.5 \%$ \\
\hline TNPU & $98.3 \%$ & $77.3 \%$ & $39.5 \%$ & $26.9 \%$ \\
\hline
\end{tabular}

Students of both Ternopil universities understood that Lyme borreliosis, an infectious disease, is spread not only in forests but also in gardens, parks, and the countryside of the region.

In the study, various methods of tick removal were presented. Most respondents (71.4\% of TNPU and $62.4 \%$ of TNTU respectively) stated that they lubricated the tick with fat (e.g. butter, oil) in order to remove it, which was thought to be the most proper method (Table 2).

Table 2. Methods of removing ticks anchored in the skin that were considered to be proper by the surveyed non-medical students of TNTU and TNPU

\begin{tabular}{|c|c|c|c|}
\hline \multirow{2}{*}{ Tick removal method } & \multicolumn{2}{|c|}{ Students of the surveyed group } & \multirow{2}{*}{ Statistical significance } \\
\hline & $\begin{array}{c}\text { (TNTU) } \\
(\%)\end{array}$ & $\begin{array}{c}\text { (TNPU) } \\
(\%)\end{array}$ & \\
\hline Pull out with fingers & 1.5 & 1.7 & $\mathrm{p}=0.9107, \chi^{2}=0.01$ \\
\hline $\begin{array}{c}\text { Remove with tweezers by } \\
\text { a single move }\end{array}$ & 26.3 & 34.5 & $p=0.1600, \chi^{2}=1.97$ \\
\hline Twist out with tweezers & 28.6 & 42.0 & $\mathrm{p}=0.254, \chi^{2}=5.00$ \\
\hline
\end{tabular}




\begin{tabular}{|c|c|c|c|}
\hline Scrape off with a fingernail & 0.8 & 0.8 & $\mathrm{p}=0.3723, \chi^{2}=0.80$ \\
\hline Apply an antiseptic & 30.8 & 36.1 & $\mathrm{p}=0.3723, \chi^{2}=0.80$ \\
\hline $\begin{array}{c}\text { Lubricate with fat } \\
\text { (e.g. butter, oil) to make it } \\
\text { get out }\end{array}$ & 62.4 & 71.4 & $\mathrm{p}=0.1293, \chi^{2}=2.30$ \\
\hline Other methods & 19.2 & 4.2 & $\mathrm{p}=0.0002, \chi^{2}=13.7$ \\
\hline
\end{tabular}

\section{Awareness of Lyme disease and ticks in students of TNTU and TNPU}

$16.5 \%$ of the students of Ivan Puluj National Technical University (TNTU) and 16\% of Volodymyr Hnatyuk National Pedagogical University (TNPU) evaluated their awareness of Lyme borreliosis as minimal, 21.8\% of TNPU students and $26 \%$ of TNTU students - as average.

The lack of knowledge of Lyme borreliosis in TNPU students was more visible in TNTU students as it concerned $42.9 \%$ of the surveyed group, whereas in TNPU it could be said about $40.3 \%$. The students of both Ternopil universities were asked to deepen their knowledge of Lyme borreliosis. A willingness to do that was expressed by $62.4 \%$ of TNTU students and $74.8 \%$ of TNPU.

About $16 \%$ of the young people of both Ternopil universities considered their awareness of Lyme berreliosis as minimal. Only $1.5 \%$ of TNPU and $4.5 \%$ of TNTU students regarded their knowledge as sufficient: $\mathrm{p}=0.4065$, $\chi 2=2.90^{*}$ - $\mathrm{p}<0.05$.

A single tick bite was reported by $31.6 \%$ of the students of the technical university and $45.4 \%$ of the pedagogical one and as many as $53.8 \%$ of TNPU and $68.4 \%$ of TNTU respondents were bitten repeatedly.

Most of the TNPU respondents (40.7\%) were bitten by a tick in the abdomen area, and $31.3 \%$ of TNTU students declared being bitten into lower limbs. The chest area was the least likely bite area according to the students of both universities (7.1\% of TNTU and $13.0 \%$ of TNPU respectively) (Table 3 ).

Table 3. Bite areas indicated by the surveyed non-medical students

\begin{tabular}{|c|c|c|c|}
\hline \multirow{2}{*}{ The area of a tick bite } & \multicolumn{2}{|c|}{ Students of non-medical universities } & \multirow{2}{*}{ Statistical significance } \\
\hline & (TNTU) & (TNPU) & \\
\hline Upper limb & 16.7 & 25.9 & $p=0.2763, \chi^{2}=1.19$ \\
\hline Lower limb & 31.3 & 35.2 & $p=0.6625, \chi^{2}=0.19$ \\
\hline Neck & 19.1 & 20.4 & $p=0.08718, \chi^{2}=0.03$ \\
\hline Chest & 7.1 & 13 & $\mathrm{p}=0.3544, \chi^{2}=0.86$ \\
\hline Shoulders & 9.5 & 13. & $p=0.08, \chi^{2}=6.8$ \\
\hline Head & 20.0 & 14.4 & $\mathrm{p}=0.57, \chi^{2}=0.4519$ \\
\hline Abdomen & 21.45 & 40.7 & $p=0.0447, \chi^{2}=4.03$ \\
\hline Other & 14.3 & 13.0 & $p=0.1455, \chi^{2}=2.12$ \\
\hline
\end{tabular}

Further, the respondents referred to the question concerning Lyme disease symptoms. The answers given are presented in Table $4.93 .0 \%$ of TNTU students considered that the main symptom of this disease is impaired concentration; $35.3 \%$ of TNPU students pointed to headaches as the main manifestations of the disease.

Table 4. Symptoms of Lyme borreliosis

\begin{tabular}{|c|c|c|c|}
\hline Main symptoms & (TNTU) & (TNPU) & Statistical significance \\
\hline Headaches & $25.6 \%$ & $35.3 \%$ & $\mathrm{p}=0.2929, \chi 2=2.82$ \\
\hline Bone pain & $11.3 \%$ & $8.4 \%$ & $\mathrm{p}=0.4460, \chi 2=0.58$ \\
\hline Arthritis & $13.5 \%$ & $15.1 \%$ & $\mathrm{p}=0.7184, \chi 2=0.13$ \\
\hline $\begin{array}{c}\text { Weakening of concentration } \\
\text { system }\end{array}$ & $93 \%$ & $10.1 \%$ & $\mathrm{p}=0.7744, \chi 2=0.08$ \\
\hline $\begin{array}{c}\text { Inflammation of the brain } \\
\text { membranes }\end{array}$ & $5.3 \%$ & $7.6 \%$ & $\mathrm{p}=0.6248, \chi 2=0.24$ \\
\hline
\end{tabular}




\begin{tabular}{|c|c|c|c|}
\hline Changes in the skin & $36.8 \%$ & $43.7 \%$ & $\mathrm{p}=0.2676, \chi 2=1.23$ \\
\hline I do not know & $49.6 \%$ & $29.4 \%$ & $\mathrm{p}=0.0026, \chi 2=11.93$ \\
\hline
\end{tabular}

\section{Discussion}

The skin of lower limbs, buttocks, groins and abdomen, as well as head in children, are the most frequent bite sites [7]. The largest group of the respondents taking part in the study (40.7\%) were bitten in the abdomen area, and lower limbs (35.2\%).

According to literature, about two thirds of the patients with Lyme disease removed the tick improperly [8]. In the presented study, various methods of tick removal were presented. The most frequent turned out to be: lubricating the tick with fat (e.g. butter, oil) $-71.4 \%$ of the provided answers, and twisting the tick out with tweezers $-42.0 \%$ of the respondents' choices.

$51.9 \%$ of the TNTU and $50 \%$ of the TNPU students stated that checking the skin after coming back home $(p=0.7064, \chi 2=0.70)$ is essential. The need of protective measures against ticks in a forest zone was understood only by $1.7 \%$ of TNPU and $12.5 \%$ of TNTU students respectively.

\section{Conclusions}

1. The students of both Ternopil universities understand that there is a risk of being infected with Lyme borreliosis, which can spread not only in forests, but also in gardens, parks, and the countryside.

2. $16.5 \%$ of the students of Volodymyr Hnatyuk National Pedagogical University (TNPU) and Ternopil Ivan Puluj National Technical University (TNTU) evaluate their awareness of Lyme borreliosis as minimal.

3. Education towards proper methods of tick removal, tick bite prevention (clothes, repellents) should become an important element of the measures taken to educate students living in the regions of high Lyme borreliosis incidence, including Ternopil.

\section{References:}

1. Andreychina MA (editor). Infectious disease in general practice and family medicine. Ternopil: TDMU, Ukrmedkknyga; 2007 (in Ukrainian).

2. Fedonyuk LYa, Chaban GP, Avsyukevich OE. Epidemiological characteristic, peculiarities of clinical course and diagnosis of systemic tick borreliosis in the Ternopil region. Tavricheskiy Mediko-Biological Vesnik. 2013; 16(1): 198-202 (in Ukrainian).

3. Shkilna M. Lyme borreliosis in forestry workers of Ternopil region. Infectious diseases. 2016; 1(83): 36-40 (in Ukrainian).

4. Vasiliev NA, Ivakhiv OL, Kachor VO, et al. Lyme disease in Ternopil region. Infectious Diseases. 2011, 2: 50-53 (in Ukrainian).

5. Kramarev S.A. Lyme disease. Health of Ukraine. 2011: 58-59 (in Ukrainian).

6. Krūmiña A, Vasiljjeva G, Lucenko I, Karelis G, Logina I. Laimborelioze: Literatūras un starptautisko vadlīniju apskats. Doctus. 2013; 8: 10-14 (in Lithuanian).

7. Bartosik K, Kubrak T, Olszewski T, Jung M, Buczek A. Prevention of tick bites and protection against tickborne diseases in south-eastern Poland. Ann Agric Environ Med. 2008; 15: 181-185.

8. Slimību profilakses un kontroles centrs. Informācija un ieteikumi izglītības iestādēm ērču pārnesto slimību profilaksei. [cited 07 June 2017]. Available from: http://www.spkc.gov.lv/ieteikumi-skolam-unbernudarziem/905/informacija-un-ieteikumi-izglitibas-iestadem-ercu-parnesto-slimibu-profilaksei (in Lithuanian). 